\title{
BARRIERS TO COMMERCIALIZATION OF LARGE-SCALE SOLAR ELECTRICITY: LESSONS LEARNED FROM THE LUZ EXPERIENCE
}

\author{
Michael Lotker \\ 1646 Folkstone Tetrace \\ Westlake Village, CA 91361 \\ $805-497-9268$
}

Sandia Contract: $87-8408$

\begin{abstract}
This report discusses the economic and policy factors leading to the initial successfu] introduction of Luz International Limiter's Solar Electric Generating Systems (SEGS). It then addresses the wide range of barriers to continued SEGS commercialization, including state and federal tax policy, avoided cost energy pricing, artificial size linitations under the Public Utility Regulatory Policies Act (PURPA), the loss of effectiveness of PURPA itself, the lack of incentives available to uilities as owners of solar electric plants, and the limited way in which the environmental benefits of this technology have been recognized. The way in which each of these barriers contributed to the suspension of new LUZ projects is highlighted. In addition, mitigation approaches to each of these barriers are suggested.
\end{abstract}




\section{DISCLAIMER}

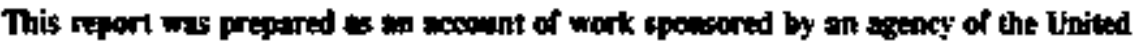

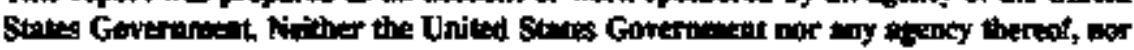

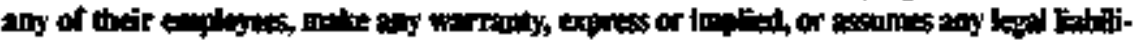

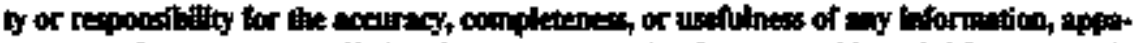

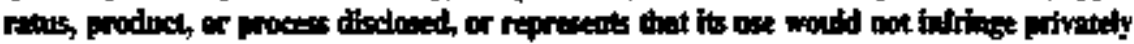

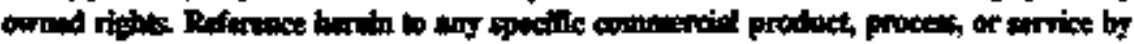

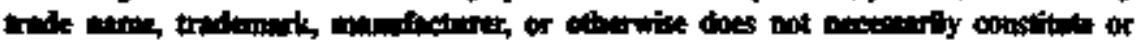

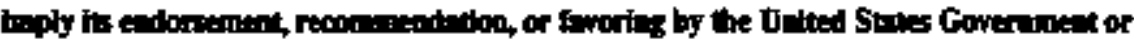

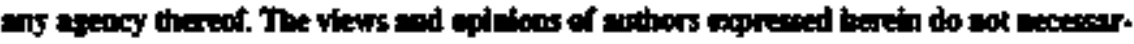

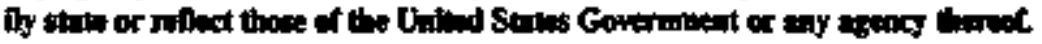




\section{DISCLAIMER}

Portions of this document may be illegible electronic image products. Images are produced from the best avallable original document. 


\section{FOREWORD}

Luz International Limited (LUZ) has been the world's most successful company in commercializing solar power plants for the utility sector. Their nine plants with a total capacity of $355 \mathrm{MW}$ today produce some $95 \%$ of the world's solar-generated electricity. Over $\$ 1.25$ billion of private financing has been raised to build the nime power plants. The atthor of this report, Michael Lotker, was LUZ's Vice President of Business Development and was actively involved in marketing the technology to utilities, their regulators and to private investors (a brief biography for Mr. Lotker is included in Appendix A of the Report). Mr. Lotker's experience and knowledge represent an important resource that will be valuable to the solar community as it attempts to market new solar technologies, both solar themal and photovoltaic, to the utility sector. Thus, as part of the Department of Energy's solar thermal program for utility applications, Sandia National Laboratories asked Mr. Lotker to prepare this report summarizing his experience and observations on existing regulatory bartiers to commercializing solar energy, and to suggest improventents in these areas. The opinions expressed are those of Mr. Lotker. 


\section{ACKNOWLEDGMENTS}

The author is indebted to Jim Verhey (who, as President of Luz Development and Finance Corporation, was his former supervisor), Daniel J. Alpert of Sandia National Laboratories and Susan Larson (a former colleague at LUZ) for their thoughtful and insightful comments on the draft of this report. 


\section{CONTENTS}

Section

Page

I Introduction and Background: The Forces That Made

Solar Commercialization Possible . . . . . . . . . . . . . 1

II The Market Response: A Partial Success . . . . . . . . . . . . 5

III LUZ: A Case Study of Successful Technology Development and Market Penetration . . . . . . . . . . . . . . . . . 8

IV Solar Therraal Commencialization: Constrained by Market and Policy Barriers . . . . . . . . . . . . . . . . . . . . . 13

v Barrier. Energy Pricing Poticy . . . . . . . . . . . . . . . . . 14

VI Bartier. Artificial Size Limitations Under PURPA . . . . . . . . . 17

VI Barrier. Annual Expiration of the Energy Tax Credits and AMT Limitations . . . . . . . . . . . . 20

VIII Barrier: Property Taxes . . . . . . . . . . . . 25

IX Barrier: Other Taxes . . . . . . . . . . . . 27

X Barrier: The Evolution of PURPA $\ldots \ldots \ldots 32$

XI Barrier: Renewable Energy Incentives Not Avaitable to Utilities . . . 34

XI Barrier. The Utility Regulatory Structure Inhibits Solar Investment . . . 35

XIII Barrier: Valuation of Environmental Externalities: Too Little Too Late . 39

XIV Conctusions and Recommendations . . . . . . . . . . 41

Appendix A: About the Author . . . . . . . . . . 42 


\section{LIST OF EXHIBITS}

Exhibit

Page

1 SEGS Electricity Cost Reduction . . . . . . . . . . . . . . 10

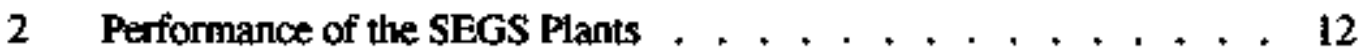

3 Energy Prices and Policy Support for Solar Energy: 1980 - 1991 , , 16

4 Comparison of State and Local Taxes Paid by Solar and Fossil Plants. 26

5 Federal, State and Local Taxation of a SEGS Ptant . . . . . . . . 29

6 Evaluating Projects With Varying Risks and Retums: The Project With a Lower Retum May Be the Best Investment . . . . . . . . 37

7 The Impact of Discount Rate Selection on PV Economics: Niagara Mohawk Case Example . 


\section{Barriers to Commercialization of Large Scale Solar Electricity: Lessons Learned from the LUZ Experience by Michael Lotker}

\section{INTRODUCTION \& BACKGROUND: THE FORCES THAT MADE SOLAR COMMERCIALIZATION POSSIBLE}

Policy concerns leading to market incentives.

The origin of serious national policy interest in market support for renewable energy can be traced to the oil price shock of 1973 when oil prices increased from approximately $\$ 3.00 /$ barrel (bbl.) to $\$ 12.00 \mathrm{bbl}$. and a similar increase in 1979 up to a kevel approaching $\$ 40.00 \%$ bbi. Long gas lines, tmprecedented increases in inflation and concern about balance of trade implications gave rise to discussion of the need for a "Manhattan Project" approach to development of alternative energy resources. Although concern for the environment was always recognized as an additional benefit of renewable energy, energy security was the focus for a level of urgency characterized by President Jimmy Carter as "the moral equivalent of war."

\section{Federal Response}

The federal response to this crisis was both institutional and legistative. Several new agencies were created to deal with the administrative needs (the Federal Energy Office which became the Federal Energy Administration eventually incorporated within the cabinet-level Department of Energy) and reseanch needs (the National Science Foundation began research later transferred to the Energy Research and Development Administration and then to the Department of Energy) of what was universally known as the "Energy Crisis." Legislatively, key initiatives were incorporated within a series of laws enacted in 1978. The most significant of these for the parpose of understanding the forces behind solar electric commercialization were:

- The Ereqy Tax Act which created a sew 15\% Energy Tax Credit (ETC) to be added to the pre-existing $10 \%$ Investment Tax Credit (ITC).

- The Public Uoilisy Regulatory Policies Act (PURPA) which mandated purchase of electricity from Qualifying Facilities (QFs) meeting certain technical standards reganting energy source (such as solar, wind, geothermal, biomass, hydro) and/or efficiency of use (stch as cogeneration). PURPA also exempted QFs from both state and federal regulation as utilities under the Federal Power Act and the Public Utility Holding Cormpany Act (PUHCA). 
The result of these federal actions was the creation of a powerful market for technologies that could meet the criteria necessary (these criteria restricted the tax credits to certain technologies, generally renewable, waste to energy and cogeneration, as well as to certain types of owners, generally non-utility) to qualify for Investrnent and Energy Tax Credits as well as for PURPA.

Although PURPA was a piece of federal legislation, specific implementation of the details was left to the states inder rules implemented by the Federal Energy Regulatory Commission (FERC). Under FERC regulations, the states' Public Utility Commissions and public utilities were obligated to adopt rules specifying how PURPA was to be implemented on a focal (utility-specific) basis. The most controversial and contested element of state implementation was the philosophy behind and calculation of avoided cost, the price that utilities were to pay to QFs for electricity. Avoided costs were intended to reflect the price that utilities would have to pay for capacity and energy in the absence of the QF. Although this might appear to be simple and straightforward, issties such as the contract term, regulatory review, utility control and a host of others would determine whether PURPA would have a significant impact in each state.

\section{California Response}

Against this background, the State of Califomia becarne the most aggressive state implementing PURPA by taking a number of key regulatory and legislative actions:

- The California Public Utilities Commission (CPUC) made it very clear that it wanted the utilities it regulates (the Investor-Owned Utitities or the IOUs) to be proactive in implenenting PURPA. It went so far as to penalize Pacific Gas \& Electric (PG\&E) in its allowed rate of retum due to a lack of activity and cooperation in this area.

- The CPUC atso mandated (throagh a cooperative process involving the utilities, QF community, and regulatory staff) a number of standard contracts to be offered to all QFs, called Interim Standard Offers which provided the following benefits to developers of renewable energy projects:

Standard Terms The utilities' enormous negotiating advantage was equalized by enacting, as standard, reasconable terms and conditions for power sales agreements. In addition, the IOUs were obligated to sign the contracts as long as the QF developer could meet the modest contract terms and deposit requirements.

- Energy Price Security Under one of the contracts (called Standard Offer $\# 4$ or $\$ O \$ 4$ ), QFs had the opportunity to commit to a fixed avoided energy cost (the portion of avoided cost that generally reflects the fuel savings to the utility) schedule for the first ten years of a project's operation (the actual terms of this option were quite 
flexible, with QFs having the opportunity to fix only a percentage of the payment and for a period less than ten years). The energy price sclyedule selected was a consensus (among the PUC, utilities and QF developers) projection of avoided energy prices for the future. The benefit for $Q F$ developers was that investors in projects would be insulated from energy price risk during the first ten years of project operation.

- Levelized Capacity Payments Under two contracts (SOH2 and SO\#4) the avoided capacity cost (the portion of avoided cost that reflects the savings in capital cost provided the utility can avoid the installation of new generating capacity) was set to be that constant value (in current dollars) over a thirty year period (the typical term of the contract) which would have the same net present value as a utility-owned combustion turbine. For example, the SEGS VIII SON2 provides for a constant payment of $\$ 187$ per $\mathrm{kW}$ per year (not adjusted for inflation) for each year of the 30 year contract. Beyond this, the QF had the opportunity to receive Bonus Capacity Payments (which could amount to as much as an additional $18 \%$ of capacity payments) if the reliability of the project were higher than that of a standard utility plant. Of particular significance to solar thermal electric projects was the fact that capacity payments were allocated into the utility's Time Of Use (TOU) periods according to the Loss Of Load Probability (LOLP) in each of these periods. In practice, this meant that the greatest share (the current percentage for Southern Califomia Edison is $84 \%$ ) of the capacity payntent wotld fall into the summer on-peak period (12 noon to $6 \mathrm{PM}$, weekdays for four months of the year), the very period when solar energy availability was highest. Much smaller capacity payments would be made during the summer mid-peak periods and still smaller amounts during the winter mid-peak period (SCE currently has no winter on-peak TOU period).

California's Standard Offer contract system was important because it provided renewable energy systems an energy pricing structure that allowed the financing of such capital-intensive technologies in a relatively stable and secure regulatory and contractual structure.

- The California legislature also enacted a number of tax key incentives for solar electric (and other systems):

- They enacted a state ETC for such systems exual to $25 \%$ of the system's capital cost (however, it is important to bear in mind that, since state taxes are deductible on federal income tax returns, the after tax benefit of the $25 \%$ state ETC is reduced - as is illustrated in Exhibit 3 below). 
- They exempted the solar portion of such systems from property taxes.

The result of these California incentives was to spur aggressive development of cogeneration and small power production facilities in the state. In fact, as of this writing, virtually all of the world's significant solar thermal electric projects are in Califomia.

Focus on Energy Security

In considering all of this activity, it is important to bear in mind that the focus of policy was on energy security and not on environmental benefits. In no case were avoided energy prices adjusted due to the mone attractive pollution rexuction characteristics of the renewable technolegies compared with fossil options. 


\section{THE MARKET RESPONSE: A PARTIAL SUCCESS}

\section{Instant Market Respanse}

As noted above, these powerful market incentives produced an almost instant response by manufacturers and developers seeking to capitalize on the state and federal tax benefits. The response was most immediate in the area of solar heating of buildings and in wind power where the relative simplicity and small scale of the technology allowed rapid production. The market was spurted on by several elements:

- The Level of Tax Benefits The combined magnitude of federal and Califomia tax benefits made these "Alternative Energy Deals" almost without equal in the tax shelter market. Especially in the early projects, investors were assured of retum of their investment through tax benefits alone.

- Utility Ercopurgement The PG\&E rate of return reduction inspired California utilities to establish departments with goals of increasing renewable and cogeneration development Utilities were often quite helpful in facilitating projects by supplying resource (e.g., wind) data and expert advice and by their willingaess to work with investment bankers involved in project development.

- Projections of Entriby Price Increases During the early 1980 s, the price of oil was in the $\$ 40.00 / \mathrm{bbl}$. range and the opinion of most experts was that it would increase at rates substantially above inflation. Since a major factor in determining the market value of renewable energy projects is based on the forecast of avoided energy prices which are in turn determined by fossil fuel prices, the expectation of continuing energy price increases created additional market demand for these projects since it reduced the perception of risks associated with future nevente streams.

Thus, the early 1980s saw a proliferation of nenewable energy technology experts (sone of whom had been funded by federal R\&D programs) becoming entrepreneurs in the renewable energy development field. Although it is true that almost none of the companies receiving direct federal support went into renewable energy system production, often, key people in these DOE supported efforts became the entrepreneurs starting successful alternative energy firms.

Generating Tax Credits and Deductions

Unfortunately, the market driven by tax incentives ofter produced products and investments that focused on tax benefits rather than energy production. This was due to a number of factors peculiar to these market incentives: 
- Qualification Regulations Since the federal ETCs relied on existing Investrment Tax Credit (ITC) regulations, there was no requirement that the equipment qualifying for the credits meet any performance standards. The only requirement was that it be placed in service during the tax year and that it be in service (even if only very linited service) during the five year recapture period (the recapture period meant that if a project were permanently removed from service before the full five year period, a portion of the ETC and ITC equal to 20\% per year would need to be repaid by the taxpayer). The rules surrounding the California ETC were even less restrictive, with no provision for recapture once the project was placed in service.

- Nature of the Incentives Since the incentives were virtually all based on the federal and California tax system, it attracted those infividuals most expert in this field - tax shelter developers. Among these individuals and companies were those who were

- Interested only in the immediate and substantial profits available from developing (as distinguished from operating) these projects;

- Sincerely interested in developing long term projects and businesses but who, trained and experienced as financial and tax experts, were extremely naive about the technical state of the att and resounce limitations of the technologies that they were developitit;

- Sophisticated entrepreneurs who understood both the technical and business challenges facing them.

The result was a virtual inundation of altemative energy projects in a wide variety of technologies (the wind projects were the most numerous) with many projects of doubtfus value from technical and long-tern economic perspectives.

\section{A Few Good Companies and Technologies Emerge}

As might be expected, arrong the large number of manufacturers and developers of renewable energy projects, a number of firms with project and business strategies that withstood the challenge of the fall in energy prices and market incentives of the late 1980 s emerged. While in some fields, such as geothermal and wind, this group included several companies covering both the equipment manufacturing and project development and finance sectors, only one company, Luz International Limited (LUZ), survived in the large scale solar electric field. The LUZ experience provides the focus for the remainder of this report. 


\section{Roles and Activities of the Utilities}

It is useful to examine the roles and activities of the utilities during this early period of rapid renewable energy development:

- Since they paid only for power actually delivered, the utilities took little or no technology or business risk on the projects. They simply served as a market for the output power under terms mandated by the CPLC.

- Even without taking nisk, the utilities gained some operational experience with the technologies by studying their performance

- In California, the utilities often objected to the level of 'subsidy' they were forced into under the SO\#4 contracts (with the ten-year fixed energy prices). Although these prices proved to be quite high relative to actual prices for natural gas, it is important to note that this was not a subsidy - it was the result of paying the anticipated reasonable price for the energy and would have been a bargain had energy prices remained high. In this regard, the utilityfratepayer risk was very similar to any utility-owned capital intensive utility project suxh as a nuclear plant. Today's nuclear plants have proven to be far more expensive than fossil fired plants due to the low price of fossil fueik. When the utility committed to the nuclear plant, it made an assumption regarding the price of fossil fuets and locked ratepayers into an SO\#4-like arrangement for the full thirty (and not ten) year life of the plant. Furthermore, in the nuclear case, the ratepayers take the full technology and performance risk of the plant; in the PURPAQF case, the ratepayers are insulated from these risks.

Thus, the effect of the incentives was to spur technology introduction and development by creating a powerful non-utility market. While many projects failed, an important few survived. In retrospect, the author believes that this approach was more productive, and perhaps even more cost-effective, than the traditional "technology push" approach of federal $R \& D$ programs. 


\section{LUZ: A CASE STUDY OF SUCCESSFUL TECHNOLOGY DEVELOPMENT AND MARKET PENETRATION}

\section{Motivation for LUZ Entrepreneurs}

LUZ, created in 1979, began with several objectives. In the author's judgment, these were;

- To provide stocktolders with a reasongbie retum on their investment. This objective was never achieved since LUZ stockbolders failed to receive any return on their investment. In this regard, it is important not to confuse LUZ stockholders with the investors/owners in the particular projects; the latter did generally receive their expected retum on investment.

- To advance solar_thermal technology_for_ts environmental benefits. Here the goal was clearly achieved with three generations of LUZ solar collectors (with each having larger size, improved efficiency and more attractive economics) designed and deployed in nine projects with a total capacity of $355 \mathrm{MW}$ and a fourth generation of collector designed.

- To provide jobs and exnorts for an Israeli subsidiary Although LUZ is a U.S. based and owned company (with only a very small percentage of foreign ownership and an even smaller fraction owned by Israelis), a clear goal of the company was to tap into the scientific and engineering expertise in the State of IsTael and to help create a significant Israeli export industry. Here too, the goal was generally successfial with Luz Industries Israel (LLI, a wholly-owned subsidiary of LUZ) among the top ten industrial exporters in the State of Israel from 1986 to 1990.

\section{Luz's Early Commercial Projects}

It is instructive to examine the early history of LUZ and its initial projects. Although the earliest efforts to market LUZ technology were directed toward the industrial process heat industry, the focus quickly stifted to the utility sector with the aggressive implementation of PURPA in Califonia. LUZ's tirst two projects were so-called "pioneer" contracts with Southern California Edison (SCE), meaning that they were negotiated before the promulgation of the Standard Offers. SCE's active support was critical in these earliest projects as the utility provided land, some seed capital, and actually paid a premium for the power produced in SEGS (an acronym for Solar Electric Generating System) I in exchange for a discount on the power produced by SEGS II. The 13.8 MW SEGS I plant was installed in 1984 at a total cost of $\$ 62$ milkion.

Although the initial capital cost resulted in electricity costs that were too high to be truly cost-effective, SEGS I proved the technology's technical feasibility and helped identify improvernents in the system. It is important to note that LUZ did receive the benefit of the 
significant federal solar thermal research program developing parabolic troughs and specialized coatings for the pipe-receivers in the techrology.

\section{Keys to LUZ Success}

As one wosld expect in the introxluction of any new technology, the LUZ pants faced significant technical and economic difficulties. As a private company, LUZ had access only to private capital and was required to keep to rigid budgets and schedules. However an important advantage of the private funding was the ability to move quickly to adjust to the demands of the marketplace and make major decisions as they were needed.

In addition to this, LUZ had the ability to continually develop the technology interactively while actually operating each new SEGS plant. A new SEGS plant was consinucted and placed into service each year, providing feedback to scientists and design engineers working on the details of the next plant and the next generation of technology.

LUZ was also able to embark on an aggnessive program to commercialize larger and more cost effective plants due to excellent market conditions and expectations:

- Market expectations were high sirce, in the early $1980 \mathrm{~s}$, the price of energy was very high and expected to grow at rates substantially above inflation.

- The level of tax credits (10\% federal ITC, $15 \%$ federal ETC, and $25 \%$ California ETC) and other tax benefits (5-year depreciation for federal and state purposes and exemption from property taxes.) made the project returns attractive even given technical performance uncertainties.

- California SOH4 contracts removed the first 10 years of energy price risk from investment in such a $Q F$.

The result was that LUZ was able to steadily reduce the cost of electricity from solar thermal electric plants (Exhibit 1). 


\section{Exhibit 1}

SEGS Electricity Cost Reduction

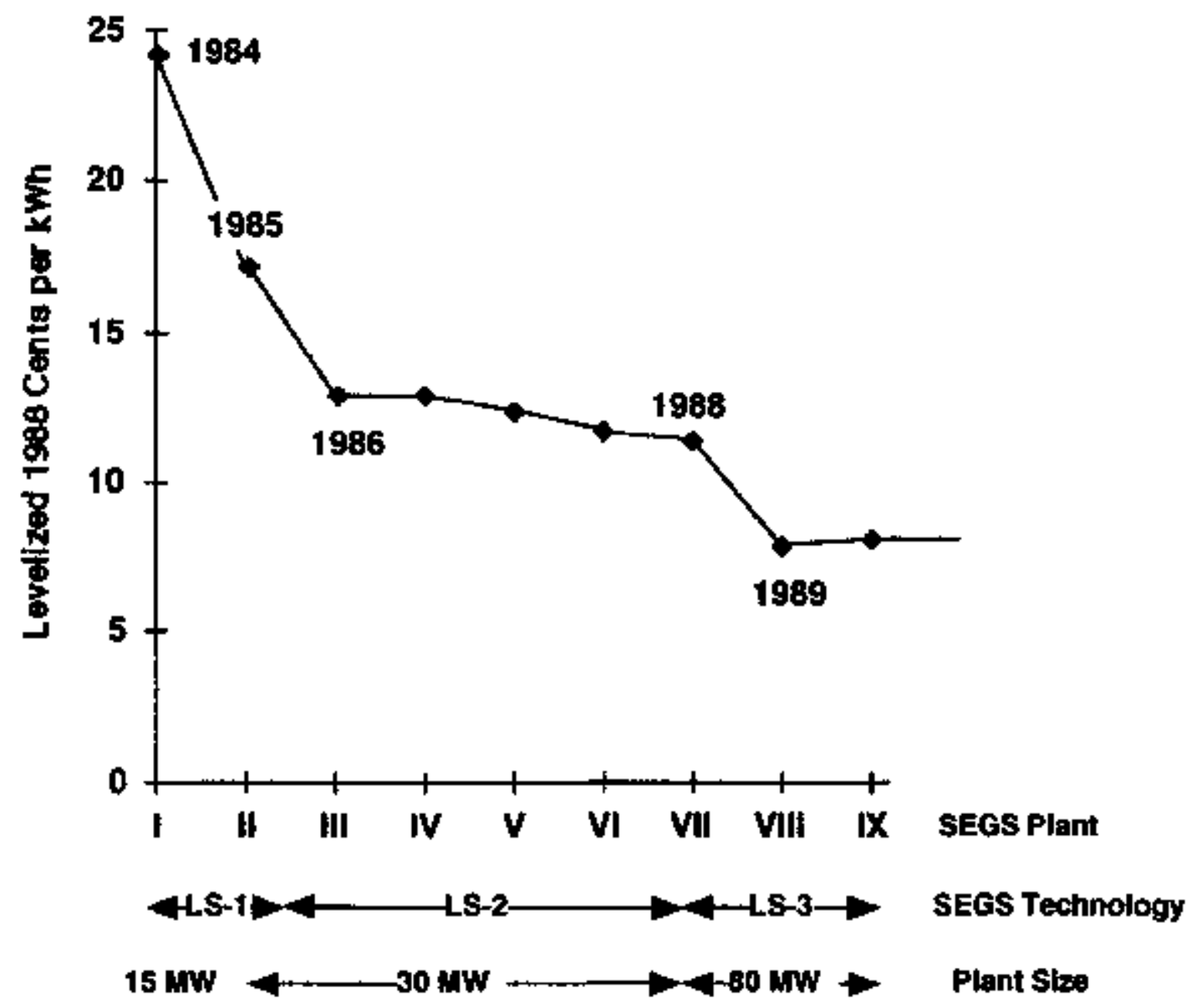




\section{Performance Record for the LUZ Plants}

The most important element in the continued success of the LUZ projects was the technical and financial performance of the individual projects. Exhibit 2 presents the SEGS plants' revenues as a percentage of projected revenues. In analyzing the SEGS track record, it is important to bear in mind that the plant's were optimized to produce maximum revenues given the specific contracts and PURPA rules in place. A number of additional points are worthy of particular note:

- Although the performance of SEGS I \& II was not up to the level of projections (a classic example of excess optimism regarding performanice of a technology not yet been deployed at commercial scale), LUZ quickly learned from the experience so that projections for later plants were more realistic. Thus early problents did not spell the end of the technology so long as the reasons for the difficulties were understood and the market for the technology remained bealthy.

- Performance for the five $\mathbf{3 0} \mathrm{MW}$ projects at Kramer Junction, Califorria (SEGS III - VII which operate under SO 4 contracts) has been excellent, with on-peak capacity facturs routinely exceding $100 \%$ (possible due to the plants' ability to operate at levels greater than $30 \mathrm{MW}$ ) and revenue levels generally consistent with projected values.

- Performance for the two 80 MW plants (SEGS VIII - IX, which operate under $\mathrm{SO}$ /2 2 contracts) has been satisfactory especially if one focuses on the solar field performance. The most significant problems encountered to date have been associated with the new gas-fired oil heaters which took the place of the boilers used in the $30 \mathrm{MW}$ plants.

Despite its technical success in constructing and operating nine projects incorporating three generations of solar thermal trough technology, the failure of energy prices to grow at expected rates (or to even maintain their level in real terms) along with a variety of other problems proved to be overwhelming for $L U Z$. Profit levels were inadequate to enable the company to build sufficient financial strength to face the chalienges of the alternative energy marketplace of the 1990s. Simply put, all of the techrological introvations and cost reductions served only to keep pace with declining energy prices and enoding incentives. The company and its investors never saw the anticipated long term increase in energy prices or valuation of environmental benefits that would add value to the SEGS plant concept. 


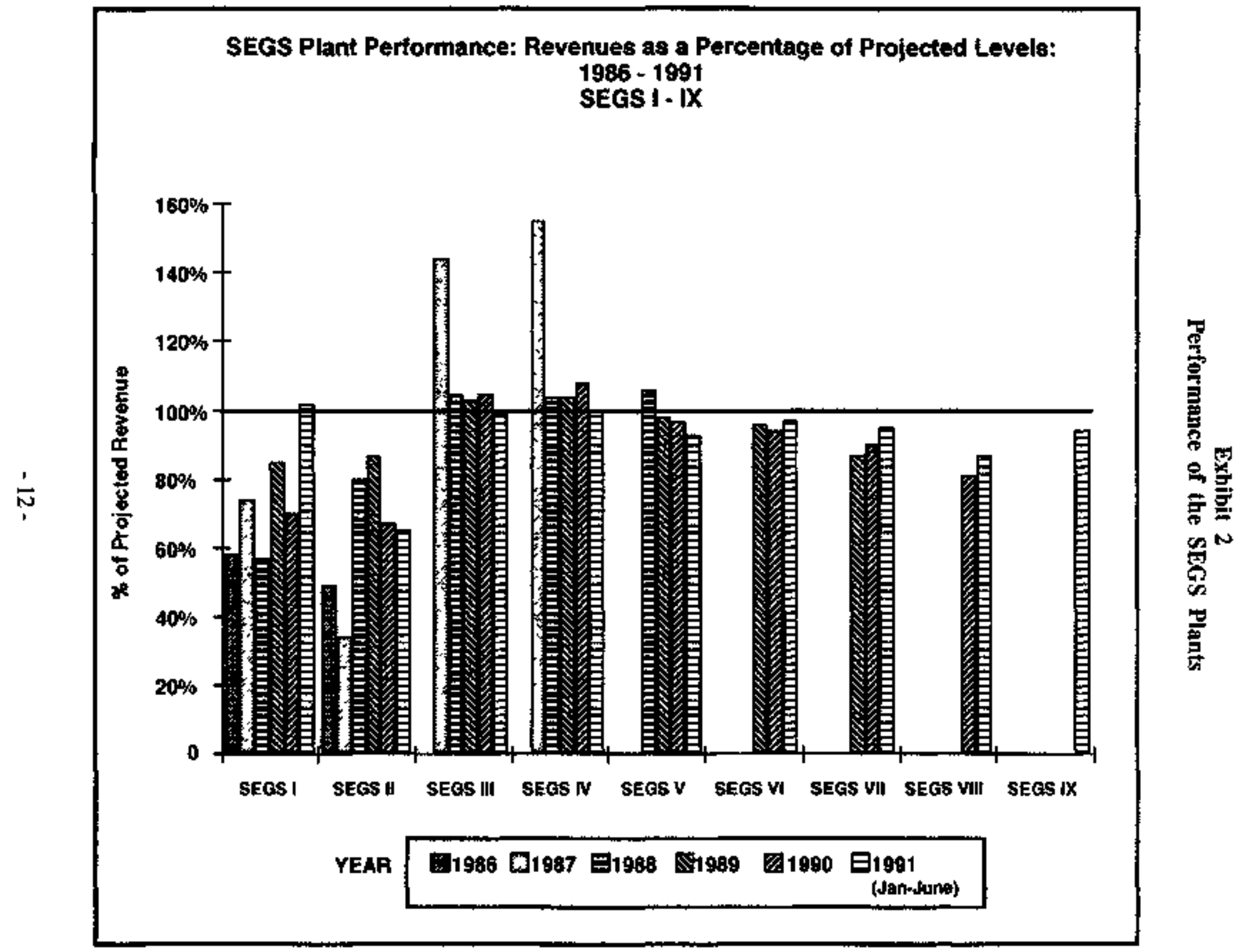




\section{SOLAR THERMAL COMMERCIALIZATION: CONSTRAINED BY MARKET AND POLICY BARRIERS}

As may be seen from the above discussion, LUZ enjoyed a unique combination of energy marketplace expectations and tax and other incentives within which to bunch its solar thermal technology. Yet, as of fall 1991, the company was on the brink of collapse. While company management accepts its responsibility for this situation and acknowledges that serious mistakes in managing growth and opportunities, were made, what cannot be overooked is the fact that a large number of barners in the aneas of taxation, regulation, policy, and in the marketplace itself resulted in a situation where LUZ managernent had to perform flawlessly in order to succeed.

The coming weeks and months will tell if it is too late for LUZ to restore itself to corporate health or if the technology will be picked up by another party. Whatever its fate, it is important to understand the barriers that thwarted LUZ as an alternative energy producer and to consider possible approaches to surmount them. The remainder of this report is dedicated to beginning that task. 


\section{V . BARRIER: ENERGY PRICING POLICY}

\section{California Standard Offers Base Energy Prices on Fossil Fuel Cost}

One of the primary advantages of renewable energy is that, as a fixed cost energy source, it serves as a hedge against future increases in fossil fuel prices. Thus, a utility considering a solar electric plant would evaluate the annual cost to the ratepayer (called "revenue requirements" in utility regulation jargon) resulting from the combination of the capital cost of the system and the utility's cost of money. It would then compare this cost with likely fuel prices and pollution cleanup costs in the future. One consideration would be the value of having a portion of the utility's generation "portfolio" in such a fixed cost energy source (see Section XII for a detailed discussion of this element).

In implementing PURPA in California, the CPUC took an approach which all but eliminated this advantage. In each of the Standard Offers put in place in the early 1980 s, the payments to $\mathrm{QFs}$ for avoided energy costs were set to be a function of the marginal fuel cost that the utility actually incurred during a given quarter (even the SOH4 contracts had the first ten years of their energy payments tied to projected oil and gas prices and their final twenty years of energy payments adjusted to actual energy prices quarterly). Afthough this made good sense in the case of cogeneration, it lead to a significant barrier in the case of solar and renewable energy technologies. By defining avoided energy costs in this way

- Ratepayers were denied the benefit of energy price diversification that should have been present as a result of renewable energy technologies. Although Califomia has done much to incorporate renewable energy into electric utility grids, the prioe paid for this energy is now tied to the current price of natural gas or oil (whichever happens to be less expensive).

- Investors in the renewable energy projects (e.g., the owners of the SEGS projects) were forced to bear the full risk of future energy prices, making the nature of the investment one of speculation in energy price futures rather than one focusing on the risks and rewards of renewable energy. As uncertainty in future energy prices increased, due both to market conditions and to the change from SO\#4 to SO\#2 (die to the enormous response to the SOH4 contracts and to falling energy prices, the CPUC suspended these contracts before suspending the SOF2 contracts), the SEGS projects became increasingly difficult to finance. For example, after the lapse of the SO\#4, which fixed energy prices for the first 10 years of project operation, the SOHz exposed investors to energy price risk immediately. Investors responded by demanding an increase in projected retums from approximately $14 \%$ fafter tax internal rate of retum) in the SEGS VII project to approximately $17 \%$ in SEGS VIII. The result was the need for LUZ to reduce the price (which is, of course, not the same as the cost) of the plant to investors in onder to be able to provide these yields. 
Thus the overall impact of this avoided cost pricing was to increase the risk to utility ratepayers (by increasing the dependence of their electricity prices on gas and oil prices) and to project investors (by making their retums highly sensitive to fossil energy prices). The increased risk to project investors resulted in reduced revenue and profits to LUZ and greatly increased risk regarding the future of LUZ. At the same time, it should be noted that this action resulted in lower risk to utility shareholders, executives and regulators.

\section{Energy Prices and Tax Credits Collapse Simultaneously}

The above discussion illustrates bow the financial health of LUZ and other Califoniafocused renewable energy companies was dependent on increases in the price of fossil fuels and (just as importantly) on perceptions and expectations about the growth in fossil fuel prices. Against this background, the reality of actual fuel price trends looms large. Exhibit 3 presents the actual price of SCE's marginal fuel (the fuet whose price actually determined the quarterly-filed avoided energy cost) in constant 1980 dollars. It also illustrates that, while energy prices were dropping some 78\% in real value, the level of federal and state tax support was dropping by more than half.

\section{Mitigation Approach}

State public utility commissions, the utilities they regutate, and self-regulating utilities (municipally-owned and cooperatively-owned utilities are typically not subject to PUC regulation) should recognize the long term value of renewable energy technologies in stabilizing energy prioes. Linking avoided energy cost to current fossil fuel prices robs ratepayers of this long term benefit and sabjects renewable energy companies and their investors to risks and costs that they may not be able to offset or accept Instead, avoided energy costs for solar and other renewable energy projects should be allowed to be largely fixed over the life of the contracts with modest adjustments for cost factors that vary with inflation such as operations and maintenance costs and backup fuel costs. This trend is beginning to be supponted in California as well as in other states.

It is important to note that even making this correction would not remove the inherent relationship between fossil energy prices and the value of renewable energy. Utilities, whether considering direct purchase of renewable energy technology or the value of the technology through a QF arrangement, wit be more likely to select a renewable energy powered plant if fossil energy prices are high. Therefore, to the extent that federal and state tax incentives are deemed to be necessary (and under current conditions of sotar thermal electric technology and energy prices, they are necessary), the level and "sunset" process of the cretits should be determined by the level of fossil energy prices. This is not a novel concept. Tax credits for certain natural gas production technologies are determined by the market price for nateral gas under current law (see section IX). 
Exhibit 3

Energy Prices and Policy Support for Solar Energy: 1980 - 1991

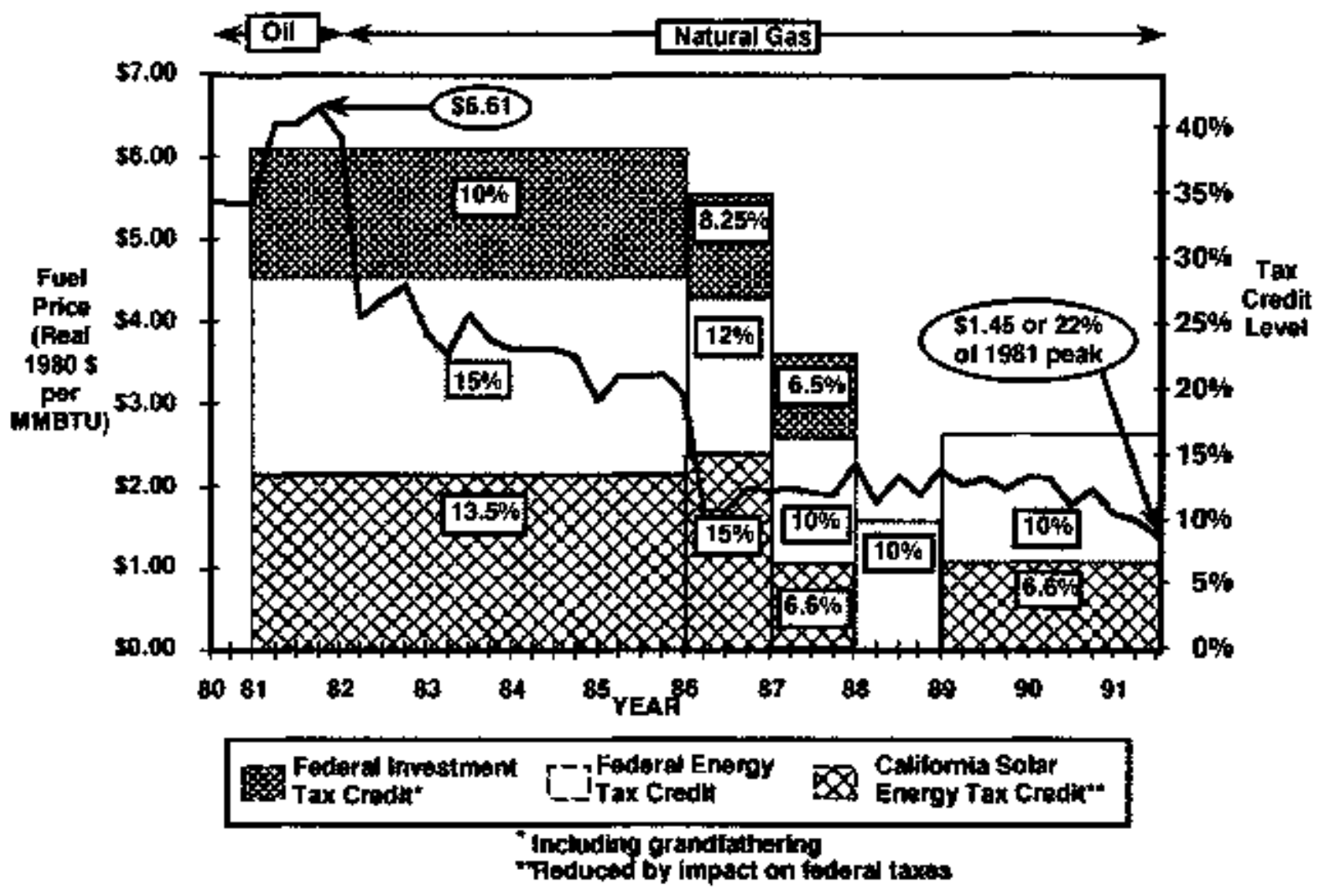

$-16-$ 


\section{BARRIER: ARTIFICIAL SIZE LIMITATIONS UNDER PURPA \\ Original Limits Under PURPA \\ PURPA created two classes of Qualifying Facilities:}

- Coperatotor: This gnoup had no size (MW) limits but had to meet certain standards regarding energy utilization efficiency.

- Small Power Producers (SPP): This group had restrictions regarding fuel soytre (generally limited to renewable or waste fuels) and, also, had a maximum size limit of $80 \mathrm{MW}$ to be a $\mathrm{QF}$ and a limit of $30 \mathrm{MW}$ for exemption from regulation as a utility under state law as well as under PUHCA.

In addition to these limitations, both classes of QFs had to meet certain other restrictions such as a 50\% limitation on utility ownership. In numerous hearings and discussions concerning the SPP size limitations, the original policy rationale for the $30 \mathrm{MW}$ size limit was never clearly stated. It appears that, during the late 1970s when PURPA was being formulated, the $30 \mathrm{MW}$ size was judged to be quite large in comparison with the then current and probable future state of the art for these technologies. The limits may also have resulted from a general concern that, if unrestricted, these technotogies might take unfair advantage of the guaranteed market that PURPA created.

The impact of PURPA limits on the early development of the LUZ technology was significant. The second SEGS plant placed in service was sized to the limit under PURPA regulation at a full $30 \mathrm{MW}$. The next five plants (SEGS III-VII) were aiso designed and constructed to be $30 \mathrm{MW}$. Moreover, operation of the plants had to be carefilly monitored to insure that the net power delivered to SCE did not exceed $30 \mathrm{MW}$ at any time. This was of concern since the plants were (and are) capable of delivering up to 33-35 MW net in either the gas or solar fueled mode (as was proven once the limit was lifted to $80 \mathrm{MW}$ ).

This artificial limit had a number of regative impacts:

- Perhaps the most serious impact was the fact that the snzall size of the plant resulted in needless excess cost. This was especially tne in retation to the power block where economies of scale are particularly significant. The magnitude of this impact can be seen from the fact that, when the size limit for the SEGS plants was lifted to $80 \mathrm{MW}$, the cost of energy from the plants dropped by about a third (Exhibit 1).

- Significant amounts of potential solar electricity were "dumped" in crder to remain below the $30 \mathrm{MW}$ limit. This was especially unfortunate from both economic and environmental perspectives since the bulk of this 
energy would have been generated during SCE's sumImer on-peak period when avoided energy and capacity payments are highest and when the solar energy would have replaced SCE's least efiicient and most poliuting peaking cajacity (especially older power plants and combustion turbines).

- The fact that such energy could not be produced meant that the total revenue projections for the plant were lower than they might have been, making the plants less profitable for LUZ and its investors.

Increasing the Limits

As the time approached for LUZ to firance the SOF2 plants beyond SEGS VII (SEGS IIIVII had been SO\#4 contracts), it became clear that additional cost reduction would be necessary to overcome the additional investor risk associated with avoided energy cost pricing. As a result, LUZ lobbied hard in Washington for a lifting of the $30 \mathrm{MW}$ limit and was successful in creating a two year moratorium in which the limit was lifted to $80 \mathrm{MW}$ and during which current and future piants could be grandfathered under the law. The law, enacted in 1987, had the following immediate irmpacts:

- LUZ was able to te-certify the existing and planned $30 \mathrm{MW}$ plants for operation above $30 \mathrm{MW}$ so as to be able to capture the benefits of operation at increased capacity levels when possible. This resulted in increased solar energy capture, higher levels of reliability during summer on-peak periods (since it was possible to actually exceed the $30 \mathrm{MW}$ in the contract), and improved economics for LUZ and its investors. In addition, LUZ was able to combine the control rooms for SEGS VI and SEGS VII achieving substantial capital and operating cost econonies.

- LUZ was able to consolidate the twelve remaining $35 \mathrm{MW}$ SOf2 contracts that it had with SCE into forr $80 \mathrm{MW}$ and one $60 \mathrm{MW}$ contracts. This aljowed SEGS VII - XII to be planned as $80 \mathrm{MW}$ projects.

- LUZ was able to certify as $80 \mathrm{MW}$ ptants its San Diego Gas \& Electric (SDG\&E) plant and six plants that it was proposing to Nevada Power Company (NPC).

The need to reduce costs still further resulted in an effort to expand the size limits when the two year window expired at the end of 1989. In 1990, Congress enacted PL 101-575 which removed the MW limits completely so long as the plant was certified as a QF before the end of 1994 and actually constructed before the end of 1999. This allowed LUZ to begin to design larger plants and allow for operation of the existing 80 MW SEGS VIII and $\mathrm{LX}$ at levels above $80 \mathrm{MW}$. 


\section{Problems for LUZ}

Although the progressive lifting of the MW limits for the SEGS piants was eventually accomplished, the manner in which the limits were implemented and removed caused a number of difficulties:

- As noted above, plant design and operation were significantly constrained during the 1980 s resulting in lost energy generation, increased capital and operating costs, and lost reverne. These were unrecoverable economic losses that servert no one's interests.

- With the limit suddenly lifted in time for the SEGS VIIl project, LUZ elected to increase the plant's size from the $30 \mathrm{MW}$ to the $80 \mathrm{MW}$ level. This was at the same time that other technological changes (including the first plant using $100 \%$ third generation solar collectors and a gas-fired oil keater rather than a boiler) were implemented, all in the SEGS VIII project. This large number of modifications adopted atl in one plant (with a total construction time of less than one year due to the expiration of the tax credits) created additional risks for the investors, who demanded higher rates of retum on their investment which transiated into reduced protits for LUZ. Although LUZ lobbied hard to facilitate such a jump in scale size, the original existence of these limits forced all of the scale-up in one large step rather than in a more natural progression.

- Even with the limit lifted to $80 \mathrm{MW}, \mathrm{LUZ}$ was constrained from designing a plant sized at an optimal level (which would have had a capacity even greater than $80 \mathrm{MW}$ ). The linit was unfair in that, by the late 1980s, avoided capacity and energy costs were being established by conventional utility or cogeneration plants which had no such limits.

- Even in removing the limit altogether, the sunset provision imposed by the legislation resulted in a crucial uncertainty in LUZZs future. Any long term investor considering supporting LUZ would have to carefully examine the likelihood that after the sunset dates of 1994 and 1999 discussed above, new solar electric QFs (existing plants are grandfathered) would once again be limited to $30 \mathrm{MW}$.

\section{Mitigation Approach}

The obvious and inmediate solution is to quickly and permanently temove the size limits on renewable SPPs. Beyond this, the history of these limits should inspire policymakers and proponents of renewable tectmologies to carefully consider the impacts of such limitations and restrictions before enacting them. 


\section{BARRIER: ANNUAL EXPIRATION OF THE ENERGY TAX CREDITS AND AMT LIMITATIONS}

Observers of national solar energy policy often point to the continued presence of tax credits for the technology as solid evidence of national cornmitment. While the tax credits have been instrumental to the survival of LUZ and other renewable energy companies, it must be noted that the erratic and inconsistent way in which they have been extended has impaired their efficacy and contributed significantly to the financial problems LUZ encountered.

\section{Enactnient and Extension}

The Energy Tax Credits (ETCs) applicable to solar thermal electric projects were enacted in the Energy Tax Act of 1978. These credits, which were also available to a host of other renewable and energy-conserving technologies, expired in 1985. Since that date, ETCs for solar electric projects have been extended on a year-to-year basis. They are, in fact, part of a group of federal tax credits (sometimes call the "Extenders") for research and development, housing and other areas that are considered each year by the U. S. Congress. Typicaliy, Congress thas extended the group of credits for a year at a time so as to expire on December 31 of the year. The situation is compounded in California where, although the Solar Business Tax Credits were extended for four years, they are not applicable for projects larger than $30 \mathrm{MW}$ if the federal tax credits are not in place.

\section{Impact of Annusal Expiration of the ETCs}

This annual expiration of the ETCs means that each SEGS plant has faced a very firm deacline for equipment placement in service. Thus, each construction period has been characterized by a tremendous focus on completion and generation of some electricity by December 31 of the construction year. LUZ has been required to back its guarantee that the investors will receive their tax benefits in the year planised by creation of a Letter of Credit (LC) backed by cash or other security. In practice, this means that any delay beyond the last day of the year would result in very substantial losses for the company. Compounding the risks to the company is the fact that, in each year, one of the following factors delayed the commencement of construction:

- Permitting: In order to begin construction of any thesmal power plant of $50 \mathrm{MW}$ or more, a permit is required from the Califormia Energy Commission (CEC). This permit, called an Authorization for Construction (AFC), is granted only after a long (one to two year) process including extensive public hearings. Delays car and often did occur due to specific technical issues, landowner intervention (where the intervenor's objective may have been to improve his bargaining position for sale of a particular parcel), intervention by other parties such as unions hoping to organize the construction force, and need for approvals by other regulatory bodies such as the CPUC, California Department of Fish and Game, and others. 
- Financing: Depending on the specific project and plan for financing construction, the ability to close dett, equity or construction fintancing could delay the commencement of constnuction.

- Legistation: In 1991, construction on SEGS X was delayed pending approval by the California legislature and govemor of kegislation extenting expiring property tax exemptions for the solar portion of the SEGS projects (see section VIII for a more complete discussion of this factor).

As a result of these factors delaying the start of construction on a SEGS project and the annual expiration of the ETCs fixing the completion date, the construction period was often forced to be much shorter than optinal. Typical construction periods were ten to twelve months, with SEGS VD and SEGS IX being completed in a period of little more than seven months from ground breaking to placement in service. The regative impacts of this accelerated construction activity were pervasive, affecting aimost every activity within the company. The following ane representative of the kinds of impacts that resulted:

As noted above, LUZ was forced to post the equivalent of cash bonds to insure that investors would receive their tax benefits. This meant that a significant portion of LUZ revenues were tied up in these LCs for extended periods of time (even beyond the placement in service dates since receipt of tax benefits could not be assured for several years following the end of the tax year).

- Although they had the benefit of this guarantee, sophisticated investors knew that LUZ's failure to meet this deadline would significantly affect the viability of the company and of existing projects. They therefore demanded and received a higher return on their investment (reducing the profit to LUZ) due to this increased project risk.

- Investors were able to secure even higher rates of return because they knew that LUZ was under significant time pressure to comptete negotiations to close financing on the project. As financing deadlines approached, LUZ had little choice but to agree to investor demands regarding a multitude of significant "deal points."

- Companies supplying goods and services to LUZ also realized the risks that they were taking by doing business with LUZ. Even under the most optimistic of assumptions, vendors realized that they would need to finance their scope of supply to LUZ. Final payment would not be received until final project financing and unil many of the retained funds were allowed to flow to LUZ Recognition of these risks meant that the 
vendors would charge a significant risk premium (the precise amount is unknowable) in the price of the goods and services, a premium that LUZ could ill afford but one that was unavoidable since there were few suppliers that were willing to take the risks involved in working with LU'Z and insufficient tirne to conduct an orderly bidding process to secure the best terms and conditions. Unfortunately, recent history has borne out the worst fears of many of these suppliers.

- Constnction and other lenders to LUZ, knowing of the time pressure placed on the company and risks involved, could and did charge high premiuns for the short term loans necessary to finance corporate and consenuction operations until the closing of financing.

- In 1989, LUZ agreed to unionize construction of SEGS IX and successive plants, adding significantly to the projects ${ }^{\dagger}$ cost. In negotiating this contract, the union had a powerful ally in the calendar in that they could hold up the SEGS VIII construction permit by delaying CEC proceedings as well as jeopardizing extension of the federal and state ETCs.

- A more subtle yet real impact was the degree to which each of the above factors dominated the LUZ management agenda A delay which might be considered routine and insignificant on a conventional utility generation construction project would be life-threatening to LUZ, demanding the immediate attention of LUZ management and advisors. This continuing threat was exhausting of resources and time and made it extremely difficult for management to focks on issues relating to the long term health and future of the company.

Where any of the above factors resulted in increased costs, the costs came out of LUZ's bottom line. SCE was neither obligated nor allowed by the CPUC to pay more for the solar energy due to these increased costs. Similarty, investors would not accept lower retums than those dictated by market conditions and perceived project risks.

1990 ETCs Extended for Only Nine Months

In 1989, the ETCs were once again extended but for only a nine-month period such that the expiration date was fixed to be September 30, 1990 rather than December 31 of that year. This was a result of a compromise between two competing proposals for six and twelve month extensions of the "Extenders." Thus, the constnuction period for SEGS IX (an 80 MW plant with some $\$ 00,000$ square meters of mirrored area in its solar field) was reduced from a planned ten to seven months (given the fact that the construction permit was granted in Febriary) with all of the negative impacts discussed above. Although LUZ was successful in placing the plant in service by the deadline, the cost of meeting this deadline consumed the remaining net worth of the company putting LUZ is a much weakened 
condition for 1991. (It is interesting to speculate on the outcome if the ETCs had been extended for only six months: construction would not have been attempted and LUZ would have gone into a cash-conserving holding mode until a longer term ETC extension was secured. In the final analysis, the company might have been in a stronger position today.)

Ironically, the ETCs were extended once again in late 1990 to expire on December 31 , 1991. Although many observers are optimistic about extension to the end of 1992 or later, as of this writing, the ETCs have not been extended and the lack of certainty regarding their extension has had a significant negative impact on LUZ's ability to secure "workout" financing.

\section{Alternative Minimum Tax Limitations}

In order to eliminate certain tax shetter abuses and to ensure that taxpayers pay some minimum level of tax, Congress created a minimum level of tax called Altenative Minimum Tax (AMT). In computing AMT, the solar ETC is not allowed and depreciation of solar energy property is calculated using a twelve-year (rather than a five-year) life. Since many of the large corporations who might be potential inyestors in LUZ projects are in an AMTlimited situation (or, more typically, cannot be sure that they will not be subject to AMT), the investor pool available to LUZ was significantly reduced. The result was weaker demand for investment in LUZ projects resulting in the need for higher yields in order to altract investors.

In reviewing AMT policy, it is important to note that, under current law, certain preferences are allowed in computing AMT tiability of taxpayers with investments in other types of energy production such as drilling costs associated with oil, gas, and geothernal properties. The benefits associated with oil and gas production are increased if oil prices are below $\$ 28 / \mathrm{bbl}$. in the prior year.

\section{Bottom Lines}

When Congress enacted the ETCs, it calculated the cost to the nation assuming the credits were to be used. The cretits are the price the nation is willing to pay to eacourage solar and other altenative energy technologies. Since LUZ and other renewable energy development firms bave been able to make use of the credits over the years, taxpayers have in fact borne some of their cost. However, the central goal of the credits, to create a sound industry capable of surviving without such incentives, has not been realized and this is due in part to the limitations described above. Thus, taxpayers have paid the price but not received the key anticipated benefits of the ETCs.

\section{Mitigation Approach}

The resolution of the problens described above is as simple as it is politically fifficult. The Energy Tax Cnedits and other incentives designed to foster the developrnent of solar and renewable energy technologies should be estabiished on a long term basis. 
If the ETCs continue to be extended on a more limited basis, a "grandfathering" provision shoild be provided that would remove some of the excessive risk associated with the current expiration provisions. Such a provision would insure that all of the appropriate expenditures on a project would be eligible for the credit if the following conditions were satisfied prior to the termination date:

- The project is constructed pursuant to a specific plan in existence on the termination date,

- The construction of the project begins at the site on $\alpha$ before the termination date, and

- More than $50 \%$ of the value of the project was incurred or committed on or before the termination date.

Beyond this, Congress should set the level of the credit and its expiration according to the price of oil and/or natural gas. This would be similar to incentives associated with other forms of energy production such as Enhanced Oil Recovery (EOR). Specifically, the phase out mechanism for EOR is tied to the price of domestic oil, with full credit fixed to a $\$ 6 / \mathrm{bbl}$, price and phase out at \$28/bbl. (in 1990 dollars adjusted for inflation).

Moreover, the benefits of ETCs and accelerated depreciation should be allowed in calculation of Alternative Minirnum Tax. In addition, if other approaches to achieving equity in taxation of renewable energy projects are desired, the option of extending tax exempt financing to them should be explored. 


\section{BARRIER: PROPERTY TAXES}

\section{Logic Behind Property Tax Exemption}

The solar portion of a SEGS plant may be thought of as the fuel source for the plant. As such, it takes the place of the gas, oil or coal to be supplied over the life of the plant. When a utility (or other owner) of a fossil fuel-fired plant purchases fuel for the plant, property taxes (or their equivalent) are not paid to the local city or county. In the case of the solar plant, since the solar field represents real property, it would incur a property tax liability unless exempted.

\section{The Californis Story}

In the case of California, the property tax rate was fixed by Proposition 13 to be $1 \%$ of the value of the solar property. In practice, this represents approximately $10 \%$ of the annual revenue of the plant. Thus, payment of property taxes on the solar field would represent the equivalent of a $10 \%$ increase in the cost of solar energy. The impact on LUZ would be a required reduction in the SEGS selling price of about the same percentage.

Responding to the heavy property tax burden, California exempted solar property from taxation for each of the SEGS plants (in actuality, the law provides that construction of a solar electric plant does not trigger a re-assessment of the property for property taxation purposes). At the end of 1990, when this exemption expired, an extension was passed by the legislatume but vetoed by the Governor. The Legislature again enacted the exemption in early 1991 amid considerable controversy that it represented a "single company tax give away." The situation was further complicated by the substantial budget deficit that the State faced in 1991. Thus, even though the bill was passed by more than a two thinds bipartisan majority in both houses, and even though the SEGS plants would still pay significant levels of property and other taxes, the bill was not signed into law until May 15, 1991.

Unfortunately, this late enactment, combined with the December 31, 1991 expiration of the ETCs, meant that SEGS X would have to be constructed in about seven months, Although LUZ had been successful in constructing SEGS IX in this short time frame, the weakened state of the company combined with other negative factors (such as further declines in energy prices and the soft market for energy investment equity) made it impossible to secure the construction financing needed to continae construction of the project and operation of the corporation itself. Shortly thereafter (in early July), Luz International Limited terninated virtualiy all personnel not directly associated with operation of the existing plants.

Comparison of State and Local Taxes Paid by Solar and Fossil Plants As part of its analysis of the impact of the Califomia legislation extending the property tax exemption for solar property, LUZ compared the property taxes paid by the SEGS plants to those paid by a typical gas fired plant. That aralysis, presented in Exhibit 4, illustrates that, without a property tax exemption, the solar plant would pay more than four times the level of taxes relative to a gas fired plant. 


\section{Exhibit 4}

Comparison of State and Local Taxes Paid by Solar and Fossil Plants

$\begin{array}{ccc}\text { Utility } & 80 \mathrm{MW} & 80 \mathrm{MW} \\ \text { Owned } 80 \mathrm{MW} & \text { Solar Plant } & \text { Solar Plant } \\ \text { Gas Fired } & \text { With Property } & \text { Without Property } \\ \text { Plant } & \text { Tax Exeprotion } & \text { Tax Exemption }\end{array}$

Sales Tax

$\$ 1,790,859$

$\$ 6,960,937$

$\$ 6,960,937$

Annual

Property Tax

532,900

83,800

$2,073,800$

Total Property

and Sales Tax

(30 Year Present

Value)

$\$ 6,814,459$

$\$ 7,750,912$

$\$ 26,510,472$

It is noteworthy that, even with the solar portion of the ptant exempted from property taxes, the sobar plant would still pay a higher amount than an equivalent gas fired plant Without the exemption, the state and local tax burden becomes excessive.

\section{Mitigation Approach}

Several states have recognized the inequity of taxing solar energy systems at levels subsantially higher than those of fossil fueled plants. It is critical that this imequity be corrected and the Department of Energy could help by sponsoring a study of taxes paid by various energy technologies and making the results of that study available to the states along with a model property tax code for solar power plants. 


\section{BARRIER: OTHER TAXES}

The discussion of property taxes in Section VII highlights but one kind of tax difference between solar and fossil power plants. In evaluating overall tax equity, a wide range of taxes need to be considered. The following discussion highlights some of the major areas of tax inequity.

\section{Sales Tax}

The owners of the SEGS plants pay a significant amount of sales tax on the equipment they buy to construct the plants (see Exhibit 4). This is in contrast to the natural gas purchased by fossil plant owners which is generally exempt from sales taxes. Once again, this is a significant cost issue in Califomia where current sales taxes are in excess of $8 \%$.

\section{Payroll Taxes}

Since the construction of the solar field involves substantial effort (approximately one million man-hours for an $80 \mathrm{MW}$ solar fieid), a considerable portion of the cost will ullimately be paid to federal, state and local goveriments in the form of payroll taxes, including:

- Federai and state income taxes

- FICA (Social Security) and Medicare taxes

- Other payroll-related taxes such as those relating to disability

Once again, this level of taxation should be compared to that associated with the use of matiral gas, oil or coal which generally provides little or no tax revenues to states and localities and much reduced revenue to the federal treasury.

Other Taxes

The high capital cost of a SEGS plant and the nature in which it is financed result in the following additional taxes:

- Taxes on contractor and stibcontractor's profits from constructing the solar field

- Taxes on construction period interest and interest earned by long-term lenders

- Taxes on profits eamed by the equity investors

- Payroll taxes resulting from the maintenance of the field. This expense may be significantly greater than maintenance of similarly sized fossitfired planks since solar field maintenance is labor-intensive. 
Exhibit 5 presents a LUZ estimate of the taxes that would be paid by SEGS $X$ had it been constructed in 1991.

Tax and Other Advantages for Conventional Energy Technologies It is beyond the scope of this paper (and beyond the author's expertise) to identify and detail alt of the tax subsidies for fossil, hydro and nuclear energy. However, at least one example of such a subsidy is the ability for gas and oil drillers to depreciate costs far beyond actual costs incurred in drilling. Landfill gas developers receive a tax credit that is phased out when the price of oil reaches $\$ 29.50$ in 1980 dollars adjusted for inflation, Other non-tax advantages currently enjoyed by nuciear energy is the limit on liabitity effected by the Price-Anderson Act and the cost of protecting the public that is inherent in the Nuclear Regulatory Commission and DOE budgets devoted to this end (this is not to say that these activities should be discontinued, only that their cost should be borne by the technologies when "free market" policy decisions are being made). The delivered price of coal is lower than it would be if coal vendors had to bear the true price of rail transportation, hability for black lung disease and other safety related factors. Also deserving further consideration are the substantial levels of R\&D fanding that other energy technologies receive from the DOE.

\section{Mitigation Approach}

While each of the tax issues identified above can be addressed individually and collectively in an analysis of the tax liabilities of the various energy technofogies, it is important for policy makers to understand that when proponents of solar and renewable energy seek improved tax treatment of these technologies, they are not seeking incentives but merely seeking equitable treatment under the tax code. The "level playing field" may seen like an oversimplified and overused phrase, but policymakers should accept that goal and the need to understand and comect the inequities built into the current tax strictuire. 


\section{Exhibit 5 (continued)}

Federal, State and Local Taxation of a SEGS Plant

Taxes

Paid During

Construction
Taxes

Paid Over 30 yr.

Plant Life

\section{State Taxes}

1. Taxes on Profits from Building the Plant

Estimated Profit of Subcontractors

Estimated Profit of the General Contractor

$\$ 1,185,750$

$2,425,933$

2. Taxes on Construction Period Interest

Interest

844,161

Fees

341,310

3. Taxes on Construction Labor

FICA

Income Taxes on Wages

4. Taxes Resulting from Maintenance of the Solar Field

Labor: Operations \& Maintenance

Materials: Operations \& Maintenance

5. Taxes From the Interest Income Earned by Lenders

Senior Lenders

Subordinated Lenders

6. Taxes on the Profits Earned by Equily

Net profit Earned by the Project Over 30 yrs.

7. Sales and Use Taxes*

Materials - Construction

$9,000,000$

Materials - Operations and Maintenance

90,000

Total State Taxes to be Paid

$\$ 15,147,154$

$\$ 65,756,823$ 


\section{Exhizit 5}

Federal, State and Local Taxation of a SEGS Pant

Taxes

Paid During

Construction
Taxes

Paid Over 30 yr.

Plant Life

\section{Federal Taxes}

1. Taxes on Profits from Building the Ptant

Estimated Protit of Subcontractors

Estimated Profit of the General Contractor

$\$ 4,335,000$
$8,869,002$

2. Taxes on Construction Period lnterest

Interest

Fees

3. Taxes on Construction Labor

FICA

$6,885,000$

Income Taxes on Wages

4. Taxes Resulting from Maintenance of the Solar Field

Labor: Operations \& Mainterance FICA

Income Taxes on Wages

Materials: Operations \& Maintenance

$\$ 7,344,000$

$4,800,000$

$1,530,000$

5. Taxes From the Interest Income Earned by Lenders

Senior Lenders

$59,657,640$

Subordinated Lenders

$17,098,260$

6. Taxes on the Profits Earned by Equity

Net profit Eamed by the Project Over 30 yrs.

$138,488,800$

Total Federal Taxes to be Paid

$\$ 28,922,982 \quad \$ 228,918,700$ 


\section{Exhibit 5 (continued)}

Federal, State and Local Taxation of a SEGS Plant

Taxes

Paid Daring

Construction
Taxes

Paid Over 30 yr.

Pant Life

Local Taxes

1. Sales Taxes on Construction*

2. Use Tax on Construction

3. Property Taxes*

Total Local Taxes To Be Paid

Summary: TotaL Taxation

Total Federal Taxes

Total State Taxes

Total Local Taxes
$\$ 28,922,982$

$15,147,154$

$1,142,500$
$\$ 228,918,700$

$65,756,823$

$11,550,000$

$\$ 45,212,636$

$\$ 306,225,523$

Percentage of the Project Attributable to Solar Energy Property

$80 \%$

$80 \%$

Additional Taxes Incurred by Solar Energy Property

* Note: Amounts for Property and Sales Tax do not match amounts in Exhibit 4 since they were calculated for different SEGS plants. 


\section{X . BARRIER: THE EVOLUTION OF PURPA}

\section{PURPA's Intent}

Congress enacted PURPA with the expressed goal of (among others) encouraging the development of certain kinds of renewable energy technologies, including solar. The chief benefits that were to be derived by a $Q F$ under PURPA were the guaranted utility purchase provisions and an attractive avoided cost approach to pricing. In practice, PURPA proved to be a huge success not only in encouraging the intended energy technologies but by illustrating the potential for independent third parties to finance, constnuct and operate utility-scale power plants.

\section{Current Reality}

By the end of the 1980s, all-source bidding for utility supply side resources had become a standard approach adopted by many state public utility commissions across the nation. This means that QFs ane competing against utility-owned plants, sales of energy and capacity from neighboring utilities, bids from Independent Power Producers (IPPs - who are not subject to PURPA restrictions), as well as other QFs. The terms of the cormpetition provide no special consideration to a project qualifying as a QF under PURPA. The two key advantages initially offered by PURPA have all but disappeared:

- PURPA's "must buy" provision has become all but meaningless now that the awards are determined as a result of all-source bidding. After the bid is complete and projects have been awarded, a QF can expect little or no capacity payment for an additional project. In practice, the QF must be the lowest cost bidder in order to be able to finance a project.

- The concept of avoided cost, once intended to provide special encouragement for QFs, now becomes defined by the lowest bid (coal, gas-fired cogeneration, economy energy, etc.). Furthermore, the bids are often evaluated against fixed projections for oil and gas prices. Thus the risk mitigation benefits of renewable energy are often given little or no recognition.

Simply put, QFs enjoy no marketplace advantage relative to utility owned or third-partyowned projects which are not QFs. One might reasonably ask why projects would seek QF status at all, especially since meeting PURPA requirements places significant constraints on

- Euel use, which must be renewable or waste-derived with auxiliary fossil use limited to $25 \%$ annually and is further constrained by other FERC relevance tests;

- Project size, cursently not limited for solar but scheduled to be restored to $30 \mathrm{MW}$ for projects certified after 1994 or constnucted after 1999.

- Onmership, with a $\mathbf{5 0 \%}$ cap on electric utility investment. 
The answer lies in the feature of PURPA that exempts QF's from state and federal regulation. The determining law in this regard is the Public Utibity Hoiding Company Act of 1935 (PUHCA). A company deemed to be a utility under PUHCA could find all of its business activities and all of the business activities of all its investors in a project regulated by the Securities and Exchange Commission (SEC). In practice, some firms, especially larger firms, have been able to carefully select development strategies that are resistant to the limitations of PUHCA regulation. LUZ never found it possible to pursue this approach since any significant problem with SEC jurisdiction could destroy a project and destroy the company. This difficulty may be resolved by pending legislation that seeks to reform PUHCA by making it easier to avoid SEC jurisdiction but this remains to be seen.

\section{Bottom Line for Solar Energy}

The practical impact of these developments is that solar technology competing for new capacity for utilities other than Califomia IOUs (the California PUC still provides that only QFs may supply independent power to JOUs, although this is expected to change) must suffer the constraints of PURPA listed above but get little or no benefits therefrom.

\section{Mitigation Approach}

Congress should explicitly question whether the factors that led it to create PURPA to favor specific approaches to meeting electric utility meeds are still relevant. If, as the author would strongly assert, they ane, then PURPA needs an immediate restoration of its power by legislative action to encourage those technologies so identified. This does not mean that all renewable energy projects would receive power purchase contracts (as was the case during the early implementation of PURPA in California), but it does mean that PURPA QFs should enjoy significant advantages relative to conventional energy technologies. 


\section{BARRIER: RENEWABLE ENERGY INCENTIVES NOT AVAHABLE TO UTILITIES}

\section{Background}

Although utilities have expressed significant interest in solar and other renewable energy technologies (in fact, utilities represent almost $50 \%$ of the equity that LUZ has raised on its projects), they have been systematically excluded from the tax benefits designed to encourage solar energy. Specifically, they are not eligible for the Energy Tax Credits or five-year accelerated depreciation that is available to non-utility owners of solar energy projects. If such benefits were available to Public Utility Property (which, as defined under the Tax Code, inchudes property owned by or leased to utilities), significant ratepayer benefits would result. Importantly, this would be true even if the utility could not use the tax benefits and elected to be the lessee/cperator of the plant.

Example of the Magnitude of the Benefits

These benefits were highlighted in an analysis that LUZ conducted for Nevada Power Company (NPC) in which it was determined that

- Eligibility for five-year depreciation and use of a lease structure would reduce the present worth of revenue requirements (PWRR - a measure of the cost to the ratepayer) by approximately $25 \%$ relative to the cost of a utility-owned plant;

- Eligibility for both the ETCs and five-year depreciation wotld redice PWRR to only two thirds of the value withost these incentives.

\section{Other Benefits of Utility Investment}

If utilities were to either directly own or be the lessee operator of a solar electric plant, many of the firancing risks that are currently borne by LUZ would be borne by the utility. Since utilities are the business entity best suited to finance such plants and bear susch risks, the cost to the ratepeyer of dealing with these risks would decrease. The author estimates that the capital cost of a SEGS plant would be reduced by as much as $15-25 \%$ if utility credit (either owner- or lessee-based) were available to the projects. This cost reduction would be a result of reduced risks borne by suppliers and lenders, reduced cost of capital to the system vendor and reduced transaction (e.g., legal and accounting) fees, anong other reasons. Even beyond this is the financing advantage of tax exempt financing available to utilities that serve one city, two or fewer counties, or are publicly-owned.

\section{Mitigation Approach}

Once again, the mitigation to this problem is straight forward. Congress should create an exemption for solar property within the definition of Public Utility Property so that such property is eligible for the Energy Tax Credits and accelerated depreciation provisions under the tax code. 


\section{XII.BARRIER: THE UTHITY REGULATORY STRUCTURE INHIBITS SOLAR INVESTMENT}

\section{Risk and Reward in Utility Investment}

Utility regulation bas served both utility owners (i.e., stockholders in the case of InvestorOwned Utilities), creditors (bondholders) and ratepayers in providing reliable energy at reasonable prices over the last 100 years. However, the system for treating risk and reward bas resulfed in a structure that does not recognize or reward solar power plants' advantages of mitigating fuel price risk.

Automatic Recovery of Fossil Fuel_Expense In a fossil-fueled plant, the risk of future increases in the price of fued is bome exclusively by the ratepayer since most utilities have automatic pass-throughs for fuet costs. Thus, a utility considering whether to avoid future fuel expenses by an investment in solar energy must consider that neither the utility slockholder nor manager will face any immediate negative consequences if the fixiintensive option is chosen.

Risks_Associated With Capital Investments On the surface, one might expect lnvestorOwned Utilities to welcome ownership of solar projects since their profit is generally tied to retum on rate base and a capitalintensive project such as a solar plant would add significantly to rate base. In practice, this factor is often outweighed by the risk of recovery of capital related expenses. In addition, rapidly growing utilities (NPC is an example) may find that they may have sufficient rate base formation from their growing transmission and distribution systems. After a utility has completed a project such as a solar plant, it must request recovery of the project's cost and its profit in what is often a hotly contested rate proceeding. The utility must be concerned with the following risks:

- That the plant will be deemed to be an "impnident" expenditure and therefore not includable in the rate base for any of several reasons:

- The plant will prove to be not needed on the completion date and disalowed in the rate base until needed.

- Certain costs for the project will be deemed to be excessive and not recoverable.

- Certain technical elements of the plant will not perform as projected and therefore be disallowed.

In practice, each of these elements has been a significant factor in recent proceedings involving nuclear and fossil-fueled plants. 
- That the utility will not be allowed to earn what it believes to be a reasonable return on its rate base for the portion of the solar plant that is included in the rate base. In fact, many utilities have chosen to invest such capital in non-regulated IPP development projects becaluse of the likelihood of achieving higher retums than are gossible in the regulated business.

Thus, the utility executive contemplating an investment in a solar plant is faced with a situation where if everything works out as hoped and expected, the ratepayer will gain the benefits of the solar investment and the utility's stockholders will eam a modest retum, while if significant probletns occurs, stockholders may bear the downside costs (and, of course, call the executives to task).

\section{Premium for Environmental Qualities}

Although this is changing (see Section XIII below), utilities and their regulators do not generally place much of a prenium on projects that do mone than simply meet minimum environmental standards. The result is that there is no premium paid for doing more than meeting requirements.

\section{Use of the Same Discount Rate for All Forms of Generation}

An are that is beginning to enjoy increased attention is use of risk-adjusted discount rates in evaluating generation technologies with very different risk profiles. This approach would recognize that a solar project faces much less risk (from the ratepayer's perspective) than, say, a gas-fired plant fron at least two perspectives:

- Energy Pics The ratepayer faces significantly lower incteases in the cost of electricity from a solar plant since the butk of the costs are fixed as capital related.

- Pollution Related Fossil fueled plants always bear the risk that future regulatory actions may increase the cost of electricity from that plant.

Traditional economics would use different hurdle rates (or target rates of retum) for the solar and gas-fired projects. This mode of analysis is similar to evaluating potential returns from two investments (Exhibit 6). The investment with the highest rate of return (e.g., a junk bond yielding $18 \%$ ) may not be more attractive than a conservative one (e.g., a Treasury Bond yielding 8\%). Clearly, an adjustment must be made for risk. If both investments are evaluated using a single discount rate, the higher yielding investment would always prevail.

In a recent paper presented at the May 1991 Workshop in Regulation and Public Utility Economics entitled, "Measuring the Cost and Benefits of New Technology: the Case of Photovoltaics," Shimon Awerbuch provided the example presented in Exhibit 7. In this 


\section{Exhibit 6}

Evaluating Projects with Varying Risks and Returns:

The Project With a Lower Return May Be the Best

Retum (\%)

Investment

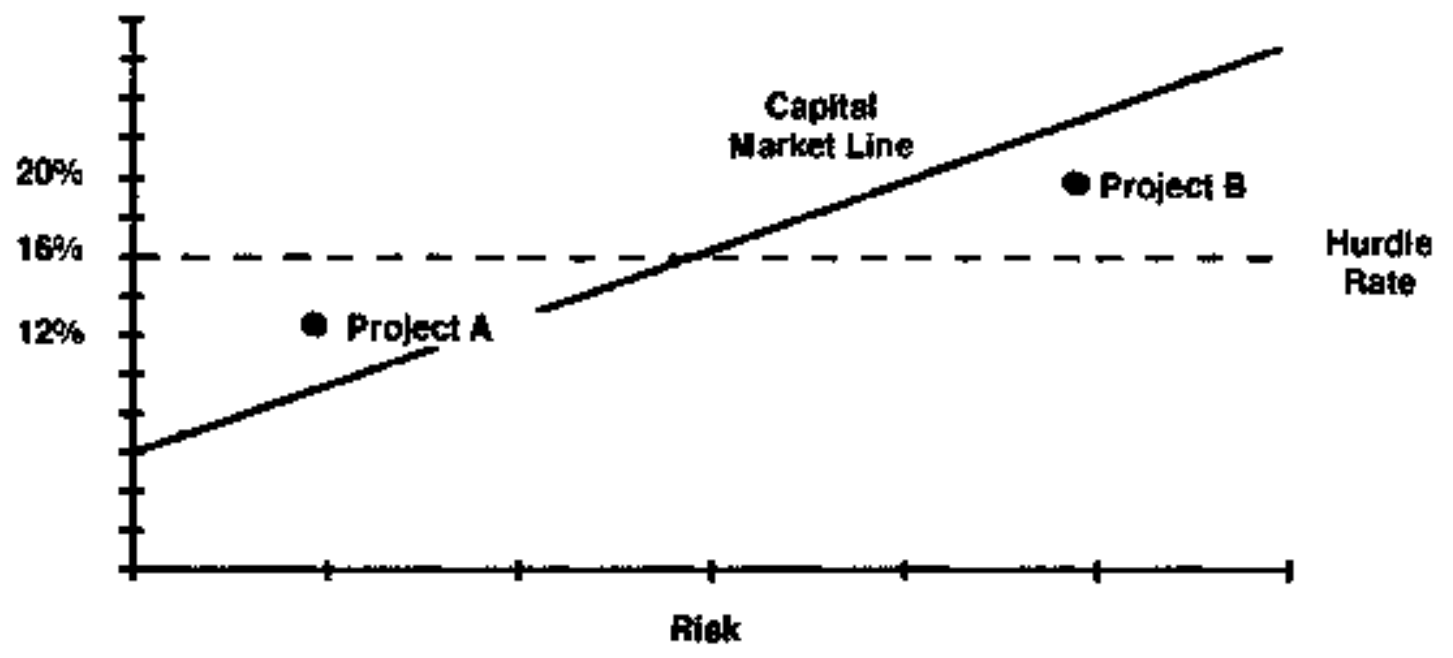

Exhibit 7

The Impact of Discount Rate Selection on PV Economics

Ningara Mahawk Case Example

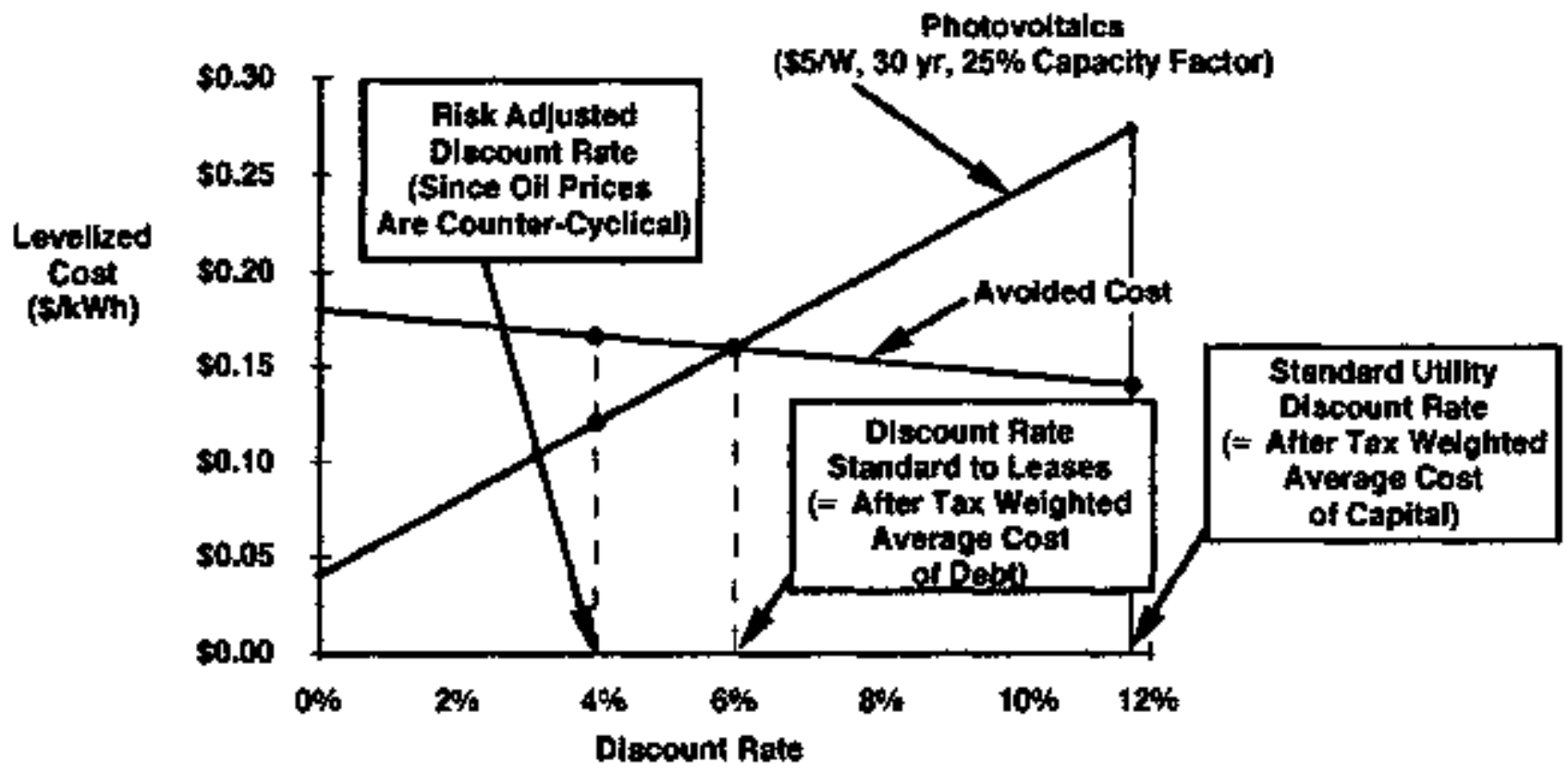

Source: "Measuring the Cost and Benefits of New Technology:

the Case of Photorolkaics," Shimon Awerbuch, Presented to the Advanced

Workshop in Regutation and Public Utility Economics, May 1991 
case, the 30-year levelized cost for a Photovoltaic (PV) plant is compared with the projected avoided cost for the Niagara Mohawk Company. At the utility's "normal" discount rate of almost 12\% (this represents the weighted after tax cost of debt and equity capital), the PV cost is about twice the $14 \mathrm{c} / \mathrm{kWh}$ of the avoided cost, clearly far too expensive by traditional utility standards. Aiternatively, if one were to use a discount rate better suited to evaluating a lease obligation (reasonable, since the payments for a solar project, either utility- or independently-owned, are generally fixed and predictable as in the case of a lease), the two projects would have levelized costs that are virtually identical. Furthermore, Professor Awerbuch argues that the PV investment should be evaluated with a still lower discount rate since it represents a diversifying element in the utility's generation "portfolio," providing price stability during periods of high fossil fuel escalation that represent the highest price risk to the ratepayer. At this lowest discount rate, the PV investment enjoys a cost advantage relative to the fossid-fuel-dominated avoided cost stream.

\section{Mitigation Approach}

Adjusting the regulatory system of our electric utilities is something that must be undertaken carefully since unintended consequences can abound. Perhaps the first step is for a state's regulators to make it clear that they want to see mone solid activity in the area of renewable energy. Regulators and consumer advocates with responsibilities to represent ratepayers before PUC procedings should determine (through public opinion surveys and other means) public attitudes concerning renewable and fossil approaches to efectricity gexeration and the public's willingness to pay more for renewable energy projects in exchange for the improved societal benefits and reduced risks that they represent. This process should inaugurate an exanuination of the ways that traditional utility regulation can be adjusted to implement the wishes of the public with regard to the utilization of renewable energy sources. 


\title{
XIII. BARRIER: VALUATION OF ENVIRONMENTAL EXTERNALITIES: TOO LITTLE TOO LATE
}

\author{
Background \\ Although solar power plants are generally reognized to have very favorable environmental \\ characteristics relative to conventional power plants, these environmental benefits have not \\ been reflected in electricity prices paid to the owners of such plants.
}

The Trend to Value Externalities

In Massachusetts, Nevada, Califomia, New York and fifteen other states, regulators have begun to establish a variety of approaches toward placing a value on the improved environmental characteristics of renewable energy tectunologies. This approach estimates the price society has demonstrated its willingness to pay as evidenced by existing requirements to clean up fossil-fueled plants. Simply put, if a scrubber is deemed to be requitred for a fassil-fueled ptant and the cost of nitrogen oxide (NOx) cleanup is $\$ 3.00$ per pound of NOx, then a "clean" plant emitting no NOx should get a credit of $\$ 3.00$ per pound of NOx its energy cutput displaces. This is called the "revealed prefenerce" approach and has been adopted in Califomia (as an "interim standard"), Nevada and Massachusetts, among others. In addition, some states have begun to approach the issue of valuing the improved contribution to local economies that renewable energy can represent.

A key question associated with environnental extemality valuation is whether to include carbon dioxide ( $\mathrm{OO}_{2}$, a "greenhouse gas" thought responsible for contributing to global warming) on the list and how to plase a value on its avoidance. A number of states have selected a value of about $1 \mathrm{c} / \mathrm{lb}$. of $\mathrm{CO}_{2}$ (about the cost of planting trees to remove the $\mathrm{CO} 2$ from the atmosphere) as a reasonable value. Another issue is how to value pollution produced out of the jurisdictional state, as in the case of power parchased from a plant in a neighboring state. Here, the trend is to treat out-of-state emissions as equivalent to in-state emissions (although this is controversial, devaluing out-of-state emissions would lead to a "pollute thy neighbor" policy).

Though controversial, the result of valting emissions in this way is to provide about a $1 \mathrm{c} / \mathrm{kWh}$ advantage to clean exergy over new gas-fired capacity and about a $4-6 \mathrm{c} / \mathrm{kWh}$ advantage over new "clean coal" capacity (the numbers can be much higher relative to dirtier existing capacity). Importantly, these numbers assume full credil for reduction of $\mathrm{CO}_{2}$; the values would drop to about a third of these if $\mathrm{CO}_{2}$ is not included in the analysis. Of cotrsse, in specific high pollution air basins such as Los Angeles, the values can be substantially highes. 


\section{Mitigation Approach}

While the trend to value avoiding emissions is praiseworthy, it must be approached on a more consistent and aggressive basis. Here again, the Department of Energy can assist by developing an acoeptable methodology for conducting full fuel cycie analyses that are necessary as a basis for the sound valuation of externalities. In addition, regulators should determine bow fatepayers value the improvements to the environment that would result from large scale implementation of renewable energy and insure that they are included in the regulatory process. 


\section{CONCLUSIONS AND RECOMMENDATIONS}

This report documents the fact that a wide variety of factors has contributed to LUZ's difficulties in continaing their cormmercialization of solar power plants, including: falling fossil fuel prices, size limitations, inconsistent tax policy and lack of incentives for utility participation. Moreover, there is often a false confidence that the renewable energy technologies will be available if and when they are called upon to play a larger rote in our energy economy. Unfortunately, the LUZ experience demonstrates that this may not be the case. It shows that a company and a technology must have room to grow if it is to survive, including a stable regulatory environment, a marketplace that values solar tochnologies' mitigation of fuel price risk, and an overall tax structume that is both stable and equitable to all energy technologies.

While the mitigation approaches presented above have identified specific actions that may be taken to adidness specific issues, the following themes must be stressed:

- Incentives must be enacted that "level the playing field" for solar and renewable energy technologies. The philosophy of the free market would indicate inaction only if today's fossil and nuclear energy technologies did not already enjoy significant incentives and subsidies. The highest priority should be an increase and extersion of the Energy Tax Crecits as well as a provision extending tax exempt financing to these projects. Restrictions on use of the credits relating to AMT should also be removed

- Incentives should be structured so as to maximize their impact in creating a long term, viable renewable energy industry. This means they must be long term, consistent, and phased out in relation to some reasonable indicator such as energy prices.

- Renewable energy technologies must be provided with a competitive environment (i.e., the rules for bidding in utility capacity procurements) which recognize and value the tectunologies' environmental and risk reduction benefits as well as their capital intensive mature. The preference of the public for renewable technology should be expressly determined and promoted at the individual state and utility level.

- The tax and other regulations that discriminate against utility ownership of renewable energy plants should be revised to correct this inequity.

In the last twenty years, this nation has responded to energy security and environmental threats in part by establishing a renewable energy industry. Simply put, we bave paid the tevition associated with learning the skills needed to provide an inexhaustible supply of clean energy for the twenty first centary and beyond. The question is whether we will allow these vital technologies to "drop out" on the verge of their graduation into widespread use on the nation's utility grids. 


\section{APPENDIX A: ABOUT THE AUTHOR}

Until recently, Michael Lotker was Vice President for Business Development for Luz International Limited. He has almost 20 years experience in the analysis, development and finance of altemative energy systems, including experience as:

- Senior Research Scientist at Northeast Utilities in Connecticut, where he conducted and supervised research projects in aneas diverse as windpower and fusion.

- Senior Associate at Booz, Allen \& Hamilton, where be conducted and managed numerous studies for the U. S. Department of Energy, the Electric Power Research Institute, utilities and other cients.

- President of Rexewable Energy Ventures, a wind power development company which installed some $\$ 50$ million in projects in Califomia and Hawaii.

Mr. Lotker holds undergraduate and graduate degrees in Physics from Queens College and the University of Illinois and is a member of Phi Beta Kappa. He is listed in American Men and Women of Science and Who's Who in the West. He is the author of numerous papers and talks on the subject of the technical feasibility and economic viability of renewable energy technologies. 